\title{
Implementasi Pendidikan Karakter dalam Budaya Sekolah di SMPN 8 Teluk Keramat Kabupaten Sambas
}

\author{
Hendrik Gustiranda ${ }^{1}$ Syamsuri ${ }^{2}$ Shilmy Purnama ${ }^{3}$ \\ ${ }^{1}$ Program Studi Pendidikan Pancasila dan Kewarganegaraan, Universitas Tanjungpura \\ Email: hendrikgustiranda7@gmail.com \\ 2 Program Studi Pendidikan Ekonomi, Universitas Tanjungpura \\ Email: syamsuri@untan.ac.id \\ ${ }^{3}$ Program Studi Pendidikan Pancasila dan Kewarganegaraan, Universitas Tanjungpura \\ Email: shilmypurnama@fkip.untan.ac.id
}

\begin{abstract}
The purpose of this research is to find problems regarding the implementation of character education in school culture at SMPN 8 Teluk Keramat. Selected qualitative research as a form of research and descriptive method as the method. As research informants from school residents, namely principals, teachers and students. Techniques in collecting data used interview, observation, and documentation techniques. The results showed that the implementation of character education in school culture was carried out through various kinds of routine activities, spontaneous activities, exemplary, and conditioning. Routine activities include: clean Friday, flag ceremony, reading the Koran before studying, praying the midday prayer in congregation in the school prayer room, and praying before and after studying. The form of spontaneous activities: giving donations to school residents in need, hair cleaning raids, and cell phone raids. Exemplary activities include: neatness of clothes for educators, and discipline of educators. Conditioning activities in the form of: slogans, clean and tidy classrooms, clean and green school environment, clean student toilets, trash cans available throughout the school environment, and water taps available in every class and throughout the school. From all routine activities, spontaneous activities, exemplary, and conditioning it will bring up integrity, nationalism, religious character, the spirit of mutual cooperation and an independent attitude.
\end{abstract}

Keywords : Implementation; Character Education; School Culture.

\begin{abstract}
Abstrak. Tujuan dari riset ini untuk menemukan permasalahan mengenai implementasi pendidikan karakter dalam budaya sekolah di SMPN 8 Teluk Keramat. Dipilih penelitian kualitatif sebagai bentuk penelitian dan metode deskriptif sebagai metodenya. Sebagai Informan Penelitian dari warga sekolah yakni kepala sekolah, guru dan para peserta didik. Teknik dalam mengumpulkan data digunakan teknik wawancara, observasi, dan dokumentasi. Hasil penelitian menunjukkan bahwa implementasi pendidikan karakter dalam budaya sekolah dilakukan melalui berbagai macam kegiatan rutin, kegiatan spontan, keteladanan, dan pengkondisian. Kegiatan rutin berupa: jumat bersih, upacara bendera, membaca Al Quran sebelum belajar, salat dzuhur berjamaah di mushola sekolah, dan berdoa sebelum dan sesudah belajar. Bentuk kegiatan spontan: memberikan bantuan sumbangan terhadap warga sekolah yang membutuhkan, razia kerapian rambut, dan razia handphone. Kegiatan keteladanan berupa: kerapian pakaian tenaga pendidik, dan kedisiplinan tenaga pendidik. Kegiatan pengkondisian berupa: slogan-slogan, ruang kelas bersih dan rapi, lingkungan sekolah yang bersih dan hijau, toilet peseta didik yang bersih, tempat sampah yang tersedia diseluruh lingkungan sekolah, dan keran air yang tersedia disetiap kelas dan penjuru sekolah. Dari keseluruhan kegiatan rutin, kegiatan spontan, keteladanan, dan pengkondisian maka akan memunculkan integritas, nasionalisme, karakter religius, jiwa gotong royong dan sikap mandiri.
\end{abstract}

Kata Kunci : Implementasi; Pendidikan Karakter; Budaya Sekolah. 


\section{PENDAHULUAN}

Pendidikan karakter merupakan sebuah usaha terencana yang diperuntukkan bagi peserta didik guna mengembangkan karakter peserta didik dengan harapan dapat menjadi manusia yang mempunyai nilai karakter yang baik dan dambakan oleh bangsa dan negara. Pendidikan karakter merupakan salah satu cara pemerintah untuk melakukan revolusi karakter agar peserta didik memiliki karakter yang mulia. Selama ini, dalam mendukung ketercapaian kompetensi dan pembentukan karakter siswa dalam pendidikan informal, belum memberikan manfaat berarti terutama dari sisi lingkungan keluarga. Kurangnya pemahaman orang tua dalam mendidik anaknya, serta kurangnya perhatian maupun aktivitas yang lain oleh orang tua siswa. Dampak sosial media serta lingkungan sekitarnya dapat berpengaruh negatif terhadap perkembangan karakter peserta didik. (Rozak \& Sayuti, 2006) juga mengatakan bahwa teman sebaya dapat memberikan dampak yang lumayan besar akan peningkatan nilai karakter peserta didik, peserta didik di dalam berinteraksi dengan lingkungan sosialnya akan cenderung tertarik dengan teman yang sebaya dengannya dan cenderung apa yang dilakukan oleh teman sebayanya memungkinkan akan dicontohkannya.

Terkait dengan karakter peserta didik belakangan ini, banyak diberitakan di media-media mengenai penyimpangan-penyimpangan yang dilakukan oleh peserta didik yang diantaranya: tidak jujur, bolos sekolah, pergaulan bebas, tawuran, hingga penyalahgunaan narkotika. Berdasarkan data (Badan Narkotika Nasional Republik Indonesia, 2019), angka penyalahgunaan narkotika di tahun 2018 menembus angka sebesar 2,29 juta orang dikalangan pelajar Indonesia (dari 13 ibu kota provinsi). Terdapat peningkatan sebesar $24-28 \%$ pelajar yang menggunakan narkotika. Di samping itu, perilaku tidak jujur pada saat ujian nasional juga telah banyak dilakukan oleh peserta didik, semenjak diberlakukannya ujian nasional sebagai standar kelulusan. Tak hanya itu, beberapa tahun yang lalu pernah terjadi kasus perundungan terhadap Audrey, salah satu siswi SMP yang mendapat pengeroyokan dari beberapa siswi SMA di Kota Pontianak yang sempat menyita perhatian publik dan menjadi trending topik media sosial twitter pada saat itu (Flora, 2019). Dari beberapa macam kasus tersebut, mengindikasikan bahwa moral dan karakter di Indonesia sudah mulai menurun.

Terkait dengan masalah remaja, terutama tentang masalah penyimpangan kaum pelajar merupakan sebuah problematika yang dirasakan sangatlah penting dan menarik untuk diperbincangkan karena yang namanya kaum terpelajar ini merupakan generasi penerus bangsa yang tentunya kemajuan suatu bangsa akan ditentukan oleh mereka sendiri. Krisis moral dan karakter ini tentunya akan memiliki dampak yang serius terhadap bangsa, karena untuk membangun sebuah negara yang maju membutuhkan generasi muda yang berbudi pekerti dan berkarakter yang baik. Maka dari itu, perlu dicari berbagai macam jalan terbaik untuk membangun dan memperbaiki karakter manusia dan bangsa Indonesia agar memiliki karakter yang baik, unggul dan mulia (Muhammad Nuh, 2010).

Masa remaja merupakan fase peranjakan anak-anak menuju dewasa. Difase tersebut peserta didik mulai mencari jati dirinya sendiri, sehingga seseorang yang sedang berada diantara masa anakanak menuju dewasa akan sangat mudah terpengaruh oleh hal-hal di sekelilingnya. Masa remaja merupakan masa penuh semangat untuk menuju kedewasaan, yang menjadi problematika adalah bagaimana seorang remaja ini membawa raganya untuk sesuatu hal yang baik dan positif (Mawardi et al., 2020). Maka dari itu, sudah barang tentu menjadi tugas dan kewajiban kita semua baik pemerintah, orang tua, maupun guru untuk membina generasi muda menjadi generasi muda yang berbudi pekerti dan berakhlak baik.

Menurut (Dodd, 1992) karakter merupakan kepunyaan manusia akan hal-hal yang baik. Pendidikan merupakan jembatan pembentuk karakter yang memiliki tujuan mulia (Dewi et al., 2019). Dan pendidikan karakter merupakan sebuah kebijakan terhadap karakter peserta didik agar dapat mencapai nilai karakter yang diinginkan oleh bangsa (Wahono et al., 2018).

Berdasarkan (Sistem Pendidikan Nasional, 2003) bahwa fungsi dari pendidikan nasional adalah mengembangkan kemampuan serta membentuk nilai karakter dan peradaban yang bermartabat. Peserta didik yang beriman dan bertakwa kepada TYME, mandiri, sehat dan berakhlak yang mulia, cakap serta kreatif. Berdasarkan (Peraturan Presiden Nomor 87, 2017) tentang penguatan pendidikan 
karakter (PPK) bahwa pendidikan karakter sebagai bagian dari strategi pendidikan nasional guna mempersiapkan generasi emas untuk tahun 2045 dengan jiwa Pancasila. Peraturan Presiden tersebut menjadi fondasi awal untuk menjadikan pendidikan karakter dalam penyelenggaraan pendidikan di Indonesia. Pendidikan karakter ditujukan untuk menumbuhkan karakter peserta didik agar bisa memberikan keputusan yang baik, menjaga kebiasaan yang baik dan menerapkannya di kehidupan sehari-hari mereka. Dalam arti lain, pendidikan karakter tidak hanya meningkatkan pengetahuan saja, tetapi juga menumbuhkan kecintaan, dan kesadaran untuk selalu berperilaku baik.

Menurut (Kemendikbud, 2017) ada 5 nilai utama yang perlu dikembangkan dalam pengimplementasian PPK, diantaranya yaitu: Religius, Nasionalis, Mandiri, Gotong royong, dan Integritas. Meskipun telah ditetapkan ada 5 nilai utama pembentuk karakter, setiap sekolah dapat menetapkan prioritas pengembangannya masing-masing. Pengembangan nilai tersebut dapat berdasarkan kepentingan dan kondisi masing-masing sekolah, sehingga dalam penerapannya kemungkinan terdapat perbedaan nilai yang dikembangkan oleh masing-masing sekolah. Sebagai lembaga pendidikan, sekolah seharusnya tidak hanya sebagai tempat menimba ilmu pengetahuan belaka, tetapi juga seharusnya sebagai tempat penyelarasan karakter generasi muda yang menyimpang. Menurut (Isnaini, 2013) salah satu pijakan dalam penerapan pendidikan karakter adalah budaya sekolah.

Budaya sekolah merupakan ciri khas sekolah yang ditandai melalui kebiasaan yang ditampilkannya, nilai yang dianutnya, dan tindakan yang ditunjukkan oleh seluruh warga sekolah (Zulaikhah, 2019). Budaya sekolah merupakan suatu model pembentukan oleh suatu kelompok tertentu (Schein, 2017). Karakter merupakan sifat batin yang mempengaruhi segala perilaku dan pikiran seseorang. Untuk mendapatkan hasil pendidikan yang maksimal, membutuhkan pembiasaan karakter yang dilakukan berulang-ulang, karena karakter tidak dapat diubah dengan proses yang instan, perlu proses yang panjang untuk menghasilkan karakter yang baik. Memiliki budaya yang baik dapat menumbuhkan sikap positif dari peserta didik (Freeks, 2015). Menurut (Kemendikbud, 2017) pendidikan karakter melalui budaya sekolah harus berfokus pada pembentukan kebiasaan yang mencerminkan nilai penguatan pendidikan karakter. Dan menurut (Kemendiknas, 2018) pembentukan pembiasaan dapat diterapkan dalam kegiatan sehari-hari di sekolah, misalnya: (1) kegiatan rutin, (2) spontan, (3) keteladanan, dan (4) pengkondisian. Dalam pembiasaan, peserta didik dipancing untuk menyadari kebiasaan baik yang mereka lakukan di sekolah, secara berproses, kebiasaan-kebiasaan yang mereka lakukan apabila diikuti dengan kesadaran dan berintrospeksi diri, lama kelamaan akan menyatu dalam kepribadian mereka sendiri. Hasil penelitian (Erlanda et al., 2021) menunjukkan bahwa pendidikan karakter religius dapat diimplementasikan dalam bentuk kegiatan rutin, spontan, keteladanan, dan pengkondisian oleh siswa dalam kegiatan sehari-hari di Sekolah. Oleh karena itu, budaya sekolah ini merupakan hal mutlak yang sangat perlu mendapatkan perhatian khusus oleh pengelola sekolah guna menciptakan lingkungan sekolah yang kondusif dan memudahkan pembentukan karakter di sekolah.

Berdasarkan observasi awal peneliti terkait pelaksanaan pendidikan karakter dalam budaya sekolah di SMPN 8 Teluk Keramat. peneliti menemukan beberapa kegiatan rutin seperti kegiatan jum'at bersih, masuk tepat waktu pukul 07.00 WIB, upacara bendera di hari senin, berdoa sebelum dan sesudah belajar, membaca Al Quran selama 10 menit sebelum belajar, hingga salat Dzuhur berjamaah di musala sekolah sebagai bentuk penanaman karakter religius yang dilakukan oleh pihak sekolah. Kegiatan spontan seperti mengumpulkan sumbangan apabila ada warga sekolah yang terkena musibah atau sedang berduka cita sebagai bentuk upaya pihak sekolah menumbuhkan rasa peduli kepada sesama, dan sikap keteladanan dari para tenaga pendidik dalam berpakaian sebagai contoh teladan untuk peserta didik, dan ditemukan juga sarana dan prasarana penunjang implementasi pendidikan karakter yang disediakan dan difasilitasi oleh sekolah seperti Al Qur'an, musala sekolah, slogan-slogan, halaman yang hijau dengan pepohonan, tempat sampah yang memudahkan warga sekolah membuang sampah, serta keran air yang disediakan di setiap depan kelas dan penjuru sekolah agar warga sekolah mudah untuk mencuci tangan. 
Berdasarkan seluruh pemaparan tersebut, memunculkan ketertarikan peneliti untuk menganalisis implementasi pendidikan karakter di dalam budaya sekolah melalui kegiatan rutin, spontan, keteladanan, serta pengkondisian di SMPN 8 Teluk Keramat Kabupaten Sambas.

\section{METODE PENELITIAN}

Dipilih penelitian kualitatif sebagai bentuk penelitian dan metode deskriptif sebagai metodenya. (Creswell, 2003) mendefinisikan bahwa penelitian kualitatif adalah penelitian yang dipergunakan dalam mengkaji probelmatika sosial dengan memberikan penjelasan melalui kata-kata secara menyeluruh. Dalam hal ini peneliti ingin mengetahui implementasi pendidikan karakter dalam budaya sekolah di SMPN 8 Teluk Keramat Kabupaten Sambas. Pengumpulan data dilakukan dengan teknik observasi, wawancara serta melalui dokumentasi. Pengambilan data untuk melihat kegiatan terintegrasi dalam bentuk program pengembangan diri yang dikembangkan oleh sekolah seperti kegiatan rutin, spontan, keteladanan, dan pengkondisian melalui metode observasi. Wawancara bersama kelapa sekolah, guru, dan peserta didik digunakan untuk memperoleh data secara mendalam yang tidak bisa ditemukan peneliti pada saat observasi, lalu mengumpulkan data dalam bentuk dokumen-dokumen yang didapat dari arsip-arsip sekolah yang dapat dijadikan sumber data. Menurut Miles and Huberman dalam (Sugiyono, 2019) ada 3 proses tahapan kualitatif dalam menganalisis data mulai dari reduksi data, penyajian, dan terakhir menarik kesimpulan data. Dalam penelitian ini, data yang telah diperoleh oleh peneliti selama di lapangan diolah serta dianalisis dimulai dari tahapan reduksi data, penyajian data, lalu dilakukan penarikan kesimpulan data (Conclusion Drawing). Dan riset ini juga melakuikan uji keabsahan data peneliti peroleh, peneliti dengan triangulasi, yakni triangulasi sumber serta triangulasi teknik.

\section{HASIL PENELITIAN DAN PEMBAHASAN}

Bentuk pelaksanaan pendidikan karakter di SMPN 8 Teluk Keramat diwujudkan melalui integrasi dalam bentuk program pengembangan diri yang dikembangkan oleh sekolah. Program tersebut diimplementasikan melalui kegiatan-kegiatan berikut ini :

\section{a. Kegiatan Rutin}

Berdasarkan hasil observasi peneliti di lapangan, peneliti menemukan beberapa kegiatan rutin yang terimplementasi melalui beberapa kegiatan, seperti dalam kegiatan membaca Al Quran selama 10 menit sebelum memulai pelajaran, kegiatan jumat bersih, upacara bendera, berdoa sebelum dan sesudah belajar, dan sholat dzuhur berjamaah di mushola sekolah di SMPN 8 Teluk Keramat Kabupaten Sambas.

Beberapa temuan tersebut sejalan dengan apa yang disampaikan oleh (Kemendiknas, 2018) bahwa kegiatan rutin adalah aktivitas warga sekolah yang dikerjakan secara rutin serta terus menerus dan selalu konsisten dilakukan, seperti berdoa ketika mau belajar dan setelahnya, upacara bendera setiap hari senin, shalat bersama, berbaris saat akan masuk kelas dan lainnya, mengucap salam kepada guru dan kepala sekolah dan sesama peserta didik ketika bertemu. Berdasarkan pendapat (Kemendiknas, 2018) tersebut dan kaitannya dengan hasil observasi peneliti di lapangan bahwa kegiatan rutin di SMPN 8 Teluk Keramat telah sesuai dengan pernyataan (Kemendiknas, 2018). Dimana peneliti menemukan peserta didik yang akan melaksanakan pembelajaran terlebih dahulu membaca Al-quran kurang lebih 10 menit. Warga sekolah yang rutin setiap hari senin melaksanakan upacara bendera, dan diberikan waktu berdoa baik sesudah maupun sebelum belajar yang dilaksanakan secara terus menerus setiap hari, hingga shalat dzuhur berjamaah yang dilakukan setiap hari di mushola sekolah. Pembentukan karakter yang tampak dalam program pembiasaan shalat berjamaah tersebut yaitu pertama, terkait dengan pelaksanaan shalat berjamaah ini yang berada di awal waktu mengajarkan pada peserta didik mengenai arti tepat waktu dalam segala hal, karakter disiplin tidak hanya masalah tepat waktu saja tetapi juga sama kaitannya dengan tertib antri wudhu, dimana peserta didik diajarkan untuk saling menghargai sesama dengan tidak menyela peserta didik lain yang sudah antri dahulu. Kemudian, memalui berdoa sebelum belajar yang dilakukan peserta didik sebelum menerima pelajaran maka dapat memberikan ketenangan batin ketika menerima pembelajaran 
Menurut (Samani \& Haryanto, 2013) kegiatan rutin merupakan kegiatan yang dilakukan secara berulang-ulang oleh warga sekolah, seperti melaksanakan upacara bendera pada setiap hari senin, mengucapkan salam dan salim ketika memasuki kelas serta kegiatan piket di kelas. Berdasarkan pendapat (Samani \& Haryanto, 2013) tersebut dan kaitannya dengan hasil observasi peneliti di lapangan bahwa kegiatan rutin di SMPN 8 Teluk Keramat telah sesuai dengan pernyataan (Samani \& Haryanto, 2013). Dimana peneliti menemukan peserta didik yang diabiasakan untuk selalu membaca Al-Quran selama 10 menit yang dilaksanakan secara terus menerus sebelum memulai pelajaran, setiap hari senin warga sekolah selalu melaksanakan upacara bendera. Guru dan siswa yang berdoa sebelum dan sesudah belajar yang dilaksanakan secara terus menerus setiap hari, hingga shalat dzuhur berjamaah yang dilakukan oleh warga sekolah setiap hari di mushola sekolah. Melalui kegiatan membaca Al Quran sebelum belajar, tampak sekolah ingin mengajarkan karakter tanggung jawab dan juga mandiri kepada peserta didik, dimana peserta didik wajibkan membawa Al Quran masing-masing dari rumah. sedangkan untuk yang tidak membawa perlengkapan akan mendapat sanksi poin agar mereka memiliki rasa patuh pada peraturan yang berlaku.

Dan (Indrawan et al., 2020) juga berpendapat bahwa kegiatan rutin merupakan suatu aktivitas kegiatan oleh warga sekolah yang dilakukan secara rutin atau terus menerus di lingkungan sekolah dengan tujuan agar warga sekolah terbiasa melakukannya dengan baik, seperti membiasakan melaksanakan upacara bendera dengan hidmat, membiasakan peserta didik duduk dengan tegak, membiasakan memberi dan menerima barang dengan tangan kanan, dan budaya mempertahankan kebersihan kelas, serta lingkungan sekolah. Berdasarkan pendapat (Indrawan et al., 2020) tersebut dan kaitannya dengan hasil observasi peneliti di lapangan bahwa kegiatan rutin di SMPN 8 Teluk Keramat telah sesuai dengan pernyataan (Indrawan et al., 2020). Dimana peneliti menemukan warga sekolah yang melaksanakan upacara bendera secara reguler dan terus menerus yang dilaksanakan setiap hari senin, dan warga sekolah dibiasakan memelihara kebersihan kelas, dan di setiap hari jumat di sekolah dilakukan kegiatan pembersihan di pagi hari atau jumat bersih. Pembentukan karakter yang terlihat melalui kegiatan jumat bersih tersebut mengajarkan kepada peserta didik tentang arti kebersamaan dalam segala hal, dapat juga memberikan efek untuk saling mengenal antar sesama warga sekolah yang disatukan oleh tugas dan tujuan yang sama, yaitu menciptakan lingkungan sekolah yang rapi dan bersih.

Maka dari itu, berdasarkan pernyataan (Kemendiknas, 2018) , (Samani \& Haryanto, 2013), dan (Indrawan et al., 2020) diatas tentang aspek kegiatan rutin dan kaitannya dengan hasil observasi peneliti bahwa kegiatan rutin yang dilaksanakan di SMPN 8 Teluk Keramat Kabupaten Sambas telah sesuai dengan pernyataan (Kemendiknas, 2018) , (Samani \& Haryanto, 2013), dan (Indrawan et al., 2020).

\section{b. Kegiatan Spontan}

Berdasarkan hasil wawancara peneliti dengan informan di lapangan, ditemukan bahwa implementasi pendidikan karakter dalam budaya sekolah melalui kegiatan spontan di SMPN 8 Teluk Keramat ialah dilakukan melalui kegiatan peduli sosial seperti dengan menginstruksikan peserta didik untuk mengumpulkan sumbangan apabila ada warga sekolah yang berduka melalui anggota OSIS. Kegiatan razia handphone, kegiatan tersebut dilakukan dengan tujuan untuk menghindari adanya video atau gambar yang dilarang norma dan agama. Dan razia kerapian rambut, kegiatan tersebut bertujuan agar peserta didik dapat berpenampilan bersih dan rapi sesuai dengan aturan yang berlaku.

Kegiatan spontan menurut (Kemendiknas, 2018) adalah kegiatan oleh peserta didik atau siswa yang dilakukan secara spontan pada waktu itu, misal membantu teman yang membutuhkan karena terkena musibah saat itu. Dengan adanya kegiatan tersebut, sekolah ingin membiasakan peserta didik untuk peka dan peduli kepada sesama. Berdasarkan pendapat (Kemendiknas, 2018) tersebut dan kaitannya dengan hasil observasi peneliti di lapangan bahwa kegiatan spontan di SMPN 8 Teluk Keramat telah sesuai dengan pernyataan (Kemendiknas, 2018). Dimana peneliti menemukan kegiatan mengumpulkan bantuan dari teman atau masyarakat berupa sumbangan apabila terdapat teman atau keluarganya yang sedang terkena bencana atau sedang berduka cita sebagai bentuk kepedulian warga 
sekolah kepada sesama, terdapat juga kegiatan razia handphone yang dilakukan oleh guru mendadak, dan razia kerapian rambut peserta didik yang lakukan oleh guru dengan tujuan agar peserta didik berpenampilan bersih dan rapi sesuai dengan aturan yang berlaku.

Menurut (Samani \& Haryanto, 2013) kegiatan spontan adalah sesuatu kegiatan yang dilakukan secara spontan, terjadi saat itu dan pada waktu tertentu, seperti membantu teman sekolah saat terjadi musibah bencana, dan menjenguk teman sekolah yang lagi sakit. Berdasarkan pendapat (Samani \& Haryanto, 2013) tersebut dan kaitannya dengan hasil observasi peneliti di lapangan bahwa kegiatan spontan yang dilakukan di SMPN 8 Teluk Keramat telah sesuai dengan pernyataan (Samani \& Haryanto, 2013). Dimana peneliti melihat kegiatan mengumpulkan sumbangan apabila ada warga sekolah yang mendapat musibah atau sedang berduka cita sebagai bentuk kepedulian warga sekolah kepada sesama, terdapat juga kegiatan razia handphone yang dilakukan oleh guru mendadak, dan razia kerapian rambut peserta didik yang lakukan oleh guru dengan tujuan agar peserta didik berpenampilan bersih dan rapi sesuai dengan aturan yang berlaku.

Maka dari itu, berdasarkan pernyataan (Kemendiknas, 2018), dan (Samani \& Haryanto, 2013) diatas tentang kegiatan spontan dan kaitannya dengan hasil observasi peneliti bahwa kegiatan spontan yang dilakukan di SMPN 8 Teluk Keramat telah sesuai dengan pernyataan (Kemendiknas, 2018), dan (Samani \& Haryanto, 2013).

\section{c. Kegiatan Keteladanan}

Berdasarkan hasil observasi peneliti di lapangan, dapat disimpulkan bahwa implementasi pendidikan karakter di SMPN 8 Teluk Keramat terlaksana melalui kegiatan keteladanan seperti dari cara berpakaian dan perilaku kepala sekolah dan guru di sekolah yang dapat menjadi rujukan oleh siswa seperti halnya peneliti temui terlihat kepala sekolah beserta guru di sekolah yang selalu berpakaian rapi dan sopan yang sesuai dengan tata tertib sekolah. Selain dari cara berpakaian kepala sekolah dan guru yang selalu rapi. Setiap guru dan siswa berupaya selalu berperilaku sopan dan saling bertegur sapa serta mengucapkan salam sesama warga sekolah.

Sikap dan perilaku terkait erat atau mempengaruhi pembelajaran (Syamsuri, 2019), sehingga hasil belajar siswa dapat diwarnai oleh sikap dan pola perilaku siswa itu sendiri. Keteladanan oleh Guru maupun lingkungannya sangat penting bagi perubahan karakter siswa. Menurut (Kemendiknas, 2018) keteladanan adalah tindakan dan sikap perilaku yang dilakukan oleh peserta didik karena hasil dari contoh yang diberikan oleh pihak sekolah dalam hal ini tenaga kependidikan. Dapat dilihat dari kesopanan, disipilin, jujur, kebersihan, percaya diri, kerajianan maupun percaya diri. Berdasarkan pendapat (Kemendiknas, 2018) tersebut dan kaitannya dengan hasil observasi peneliti di lapangan bahwa kegiatan keteladanan di SMPN 8 Teluk Keramat telah sesuai dengan pernyataan (Kemendiknas, 2018). Dimana peneliti menemukan kedisiplinan para guru dan kepala sekolah dengan hadir selalu tepat waktu sebelum bel masuk berbunyi, dan disiplin terhadap aturan dengan selalu ikut melakukan upacara bendera dihari senin bersama peserta didik. Tak hanya itu, kegiatan keteladanan terlihat juga dari cara berpakaian guru dan kepala sekolah yang selalu rapi dan sesuai dengan ketentuan, tidak berambut gondrong bagi guru laki-laki, rambut disisir rapi, menggunakan jilbab bagi perempuan, pakaian tidak ketat, hingga tidak menggunakan perhiasan secara berlebihan.

Menurut (Samani \& Haryanto, 2013) keteladanan adalah munculnya karakter dan sikap dari peserta didik yang ditimbulkan karena hasil dari meniru sikap dan perilaku Guru di Sekolah. Berdasarkan pendapat (Samani \& Haryanto, 2013) tersebut dan kaitannya dengan hasil observasi peneliti di lapangan bahwa kegiatan keteladanan di SMPN 8 Teluk Keramat telah sesuai dengan pernyataan (Samani \& Haryanto, 2013). Dimana peneliti menemukan kedisiplinan para guru dan kepala sekolah dengan hadir selalu tepat waktu sebelum pukul 07.00 WIB, dan disiplin terhadap aturan dengan selalu ikut melakukan upacara bendera di hari senin bersama peserta didik. Tak hanya itu, kegiatan keteladanan terlihat juga dari cara berpakaian guru dan kepala sekolah yang selalu rapi dan sesuai dengan ketentuan, tidak berambut gondrong bagi guru laki-laki, rambut disisir rapi, 
menggunakan jilbab bagi perempuan, pakaian tidak ketat, hingga tidak menggunakan perhiasan secara berlebihan.

Sedangkan menurut (Indrawan et al., 2020) kegiatan yang mencerminkan keteladanan yaitu suatu kegiatan yang dapat dijadikan contoh perilaku sehari-hari oleh siswa, misalnya para tenaga kependidikan yang selalu ramah, santun dalam berbicara, rapi berpakaian, datang tepat waktu, dan sopan dalam bertegur sapa. Berdasarkan pendapat (Indrawan et al., 2020) tersebut dan kaitannya dengan hasil observasi peneliti di lapangan bahwa kegiatan keteladanan di SMPN 8 Teluk Keramat telah sesuai dengan pernyataan (Indrawan et al., 2020). Dimana peneliti menemukan kedisiplinan para guru dan kepala sekolah dengan hadir selalu tepat waktu sebelum pukul $07.00 \mathrm{WIB}$, dan disiplin terhadap aturan dengan selalu ikut melakukan upacara bendera di hari senin bersama peserta didik. Tak hanya itu, kegiatan keteladanan terlihat juga dari cara berpakaian guru dan kepala sekolah yang selalu rapi dan sesuai dengan ketentuan, tidak berambut gondrong bagi guru laki-laki, rambut disisir rapi, menggunakan jilbab bagi perempuan, pakaian tidak ketat, hingga tidak menggunakan perhiasan secara berlebihan.

Maka dari itu, berdasarkan pernyataan (Kemendiknas, 2018), (Samani \& Haryanto, 2013), dan (Indrawan et al., 2020) di atas tentang aspek keteladanan dan kaitannya dengan hasil observasi peneliti bahwa kegiatan keteladanan di SMPN 8 Teluk Keramat telah sesuai dengan pernyataan (Kemendiknas, 2018), (Samani \& Haryanto, 2013), dan (Indrawan et al., 2020)

\section{d. Kegiatan Pengkondisian}

Berdasarkan hasil observasi peneliti dapat disimpulkan bahwa implementasi pendidikan karakter yang dilakukan di SMPN 8 Teluk Keramat melalui kegiatan pengkondisian ialah lingkungan sekolah yang bersih dan hijau dengan pepohonan, tempat sampah di setiap depan kelas dan penjuru sekolah, tempat mencuci tangan yang tersedia di setiap kelas dan penjuru sekolah, tata letak ruangan yang berada di sekolah yang rapi, strategis, dan bersih misalnya ruangan kepala sekolah, ruangan perpustakaan, ruangan guru, ruangan tata usaha, musala, tempat penyimpanan piala dan penghargaan, mading informasi, dan toilet yang bersih.

Pengkondisian menurut (Kemendiknas, 2018) merupakan penciptaan kondisi lingkungan sekolah sedemikian rupa guna pendidikan karakter tetap didukung dan terlaksana dengan baik, tercermin dari toilet yang bersih, tempat pembuangan sampah yang tersedia banyak lolasi, halaman sekolah terlihat hijau dengan ditanami berbagai tumbuhan, dan slogan-slogan pesan bijak yang tersedia di berbagai tempat. Berdasarkan pendapat (Kemendiknas, 2018) tersebut dan kaitannya dengan hasil observasi peneliti di lapangan bahwa kegiatan pengkondisian di SMPN 8 Teluk Keramat telah sesuai dengan pernyataan (Kemendiknas, 2018). Dimana peneliti menemukan lingkungan sekolah yang bersih dan hijau dengan pepohonan, tempat sampah disetiap depan kelas dan penjuru sekolah, tempat mencuci tangan yang tersedia di setiap kelas dan penjuru sekolah, dan toilet yang bersih.

Menurut (Samani \& Haryanto, 2013) bahwa pengkondisian merupakan kondisi yang diciptakan yang mengakomodasi keberlangsungan pendidikan karakter yaitu menjaga ruangan tetap rapi, menyediakan tempat sampah yang cukup, dan lingkungan sekolah yang asri. Berdasarkan pendapat (Samani \& Haryanto, 2013) tersebut dan kaitannya dengan hasil observasi peneliti di lapangan bahwa kegiatan pengkondisian di SMPN 8 Teluk Keramat telah sesuai dengan pernyataan (Samani \& Haryanto, 2013). Dimana peneliti menemukan lingkungan sekolah yang bersih dan hijau dengan pepohonan, tempat sampah di setiap depan kelas dan penjuru sekolah, tempat mencuci tangan yang tersedia di setiap kelas dan penjuru sekolah, tata letak ruangan yang berada di sekolah yang rapi, strategis, dan bersih misalnya ruangan kepala sekolah, ruangan perpustakaan, ruangan guru, ruangan tata usaha, musala, dan toilet yang bersih.

Sedangkan menurut (Wibowo, 2012) untuk keberlanjutan pendidikan karakter di sekolah harus di dukung dengan mengkondisikan kegiatan yang mencerminkan nilai karakter bangsa seperti 
kebersihan toilet, ketersediaan tempat sampah yang mencukupi, lingkungan sekolah yang bersih, rapi dan penempatan alat belajar yang teratur. Berdasarkan pendapat (Wibowo, 2012) tersebut dan kaitannya dengan hasil observasi peneliti di lapangan bahwa kegiatan pengkondisian di SMPN 8 Teluk Keramat telah sesuai dengan pernyataan (Wibowo, 2012). Dimana peneliti menemukan tempat sampah yang tersedia disetiap depan kelas dan penjuru sekolah, tempat mencuci tangan yang tersedia di setiap kelas dan penjuru sekolah, tata letak ruangan yang berada di sekolah yang rapi, strategis, dan bersih misalnya ruangan kepala sekolah, ruangan perpustakaan, ruangan guru, ruangan tata usaha, musala, tempat penyimpanan piala dan penghargaan, mading informasi, dan toilet yang bersih.

Maka dari itu, berdasarkan pernyataan (Kemendiknas, 2018), (Samani \& Haryanto, 2013), dan (Wibowo, 2012) diatas tentang aspek pengkondisian dan kaitannya dengan hasil observasi peneliti bahwa kegiatan pengkondisian di SMPN 8 Teluk Keramat telah sesuai dengan pernyataan (Kemendiknas, 2018), (Samani \& Haryanto, 2013), dan (Wibowo, 2012).

\section{KESIMPULAN}

Berdasarkan temuan riset yang dilakukan terkait implementasi pendidikan karakter dalam budaya sekolah di SMPN 8 Teluk Keramat dapat dipaparkan hasil penelitian berikut ini:

1. Implementasi pendidikan karakter dalam budaya sekolah di SMPN 8 Teluk Keramat terlaksana melalui kegiatan rutin yaitu, kegiatan jumat bersih yang dilaksanakan setiap hari jumat, 10 menit membaca alquran sebelum memulai pelajaran, berdoa bersama dan sesudah belajar, upacara bendera setiap hari senin, dan salat dzuhur berjamaah.

2. Implementasi pendidikan karakter dalam budaya sekolah di SMPN 8 Teluk Keramat terlaksana melalui kegiatan spontan yakni, memberikan bantuan sumbangan terhadap warga sekolah yang membutuhkan, razia handphone, dan razia kerapian rambut.

3. Implementasi pendidikan karakter dalam budaya sekolah di SMPN 8 Teluk Keramat terlaksana melalui kegiatan keteladanan yang dicontohkan oleh para tenaga pendidik seperti, berpakaian rapi, dan disiplin datang ke sekolah. Tenaga pendidik tidak hanya sekedar menyampaikan ilmu pengetahuan, namun juga mencontohkan teladan yang baik kepada peserta didik.

4. Implementasi pendidikan karakter dalam budaya sekolah di SMPN 8 Teluk Keramat terlaksana melalui pengkondisian seperti, terdapat slogan-slogan di setiap ruang kelas dan penjuru sekolah, lingkungan sekolah yang hijau dengan pepohonan yang membuat suasana belajar menjadi nyaman, tersedia tempat sampah yang memudahkan warga sekolah membuang sampah, tempat mencuci tangan yang tersedia di setiap kelas dan penjuru sekolah, tata letak ruangan yang berada di sekolah yang rapi, strategis, dan bersih misalnya ruangan kepala sekolah, ruangan perpustakaan, ruangan guru, ruangan tata usaha, toilet, musala, dan ruangan kelas yang saling berdekatan sehingga memudahkan segala urusan bagi warga sekolah.

\section{DAFTAR PUSTAKA}

Badan Narkotika Nasional Republik Indonesia. (2019, August 12). Badan Narkotika Nasional Republik Indonesia. Badan Narkotika Nasional Republik Indonesia.

Creswell, J. W. (2003). Research design Qualitative quantitative and mixed methods approaches. Research Design Qualitative Quantitative and Mixed Methods Approaches. https://doi.org/10.3109/08941939.2012.723954

Dewi, A. K. T., Degeng, I. N. S., \& Hadi, S. (2019). Implementasi Pendidikan Nilai Karakter di Sekolah Dasar Melalui Budaya Sekolah. Jurnal Pendidikan: Teori, Penelitian Dan Pengembangan, 4(2), 247-255. 
Dodd, A. W. (1992). Educating for Character: How Our Schools Can Teach Respect and Responsibility. By Thomas Lickona. New York: Bantam Books, 1991. NASSP Bulletin, 76(545). https://doi.org/10.1177/019263659207654519

Erlanda, M., Sulistyarini, S., \& Syamsuri, S. (2021). Implementasi Pendidikan Karakter Religius Melalui Budaya Sekolah di SMA Mujahidin Pontianak. Equilibrium: Jurnal Pendidikan, 9(3), 310-318. https://doi.org/10.26618/EQUILIBRIUM.V9I3.5920

Syamsuri, S. (2019). Analisis Konsep Theory of Planned Behavior Terhadap Pembelajaran Wirausaha dan Pendidikan Ekonomi Keluarga Pelaku UMKM. Jurnal PROFIT Kajian Pendidikan Ekonomi dan IImu Ekonomi, 6(2), 101-113. https://doi.org/10.36706/ip.v6i2.9795

Flora, M. (2019, April 10). Kasus Pengeroyokan Audrey, dari Kronologi hingga Petisi. Liputan 6. Freeks, F. E. (2015). The influence of role-players on the character-development and characterbuilding of South African college students. South African Journal of Education, 35(3). https://doi.org/10.15700/saje.v35n3a1086

Indrawan, I., Suherman, \& Wijoyo, H. (2020). Manajemen Pendidikan Karakter by Dr (C). Irjus Indrawan, S.Pd.I., M.Pd.I., Hadion Wijoyo, S.E.,S.H.,S.Sos.,S.Pd.,M.H.,M.M.,Ak.,CA.,QWP ${ }^{\circledR}$, Dr. Suherman, S.Kom, M.M., Dr. I Made Arsa Wiguna, SST. Par., M (z-lib.org).

Isnaini, M. (2013). INTERNALISASI NILAI-NILAI PENDIDIKAN KARAKTER DI MADRASAH. AL-Ta Lim, 20(3), 445. https://doi.org/10.15548/it.v20i3.41

Kemendikbud. (2017). Konsep dan Pedoman Penguatan Pendidikan Karakter. Kemendikbud.

Kemendiknas. (2018). Panduan Pelaksanaan Pendidikan Karakter. In Jakarta:Pusat Kurikulum dan Perbukuan.

Mawardi, I., Dewi Shalikhah, N., \& Baihaqi, A. (2020). Penguatan Pendidikan Karakter (PPK) Berbasis Budaya Islami Sekolah di MI Muhammadiyah Sidorejo Bandongan. JPPM (Jurnal Pengabdian Dan Pemberdayaan Masyarakat), 4(1). https://doi.org/10.30595/jppm.v0i0.5673

Muhammad Nuh, dkk tim. (2010). Kerangka Acuan Pendidikan Karakter Tahun Anggaran 2010. Buku Kementerian Pendidikan Nasional.

Peraturan Presiden Nomor 87. (2017). Penguatan Pendidikan Karakter.

Rozak, A., \& Sayuti, W. (2006). Remaja dan Bahaya Narkoba. Pranata Media Group.

Samani, M., \& Haryanto. (2013). Konsep dan Model Pendidikan Karakter. PT. REMAJA ROSDAKARYA.

Schein, E. (2017). Organizational Culture and Leadership Organizational Culture and Leadership. Wiley \& Sons, Inc., Idd.

Sistem Pendidikan Nasional. (2003). Undang-Undang No.20 Tahun 2003. Departemen Pendidikan Nasional.

Sugiyono. (2019). Metode Penelitian Pendidikan. Bandung:Alfabeta. 
Wahono, M., Wahono, M., \& Priyanto, A. S. (2018). Implementasi Budaya Sekolah Sebagai Wahana Pengembangan Karakter Pada Diri Siswa. Integralistik, 28(2).

https://doi.org/10.15294/integralistik.v28i2.13723

Wibowo, A. (2012). Pendidikan Karakter: Strategi Membangun Karakter Bangsa Berperadaban. Экономика Региона.

Zulaikhah, S. (2019). PENGUATAN PENDIDIKAN KARAKTER MELALUI PENDIDIKAN AGAMA ISLAM DI SMPN 3 BANDAR LAMPUNG. Al-Tadzkiyyah: Jurnal Pendidikan Islam, 10(1).

https://doi.org/10.24042/atjpi.v10i1.3558 